\title{
METAFORA TANGAN DALAM IDIOM BAHASA JEPANG BERDASARKAN TEORI METAFORA KONSEPTUAL
}

\author{
Dita Rachmawati
}

\author{
$\underline{312201600670 @ \text { mhs.dinus.ac.id }}$ \\ Universitas Dian Nuswantoro
}

\begin{abstract}
This thesis is a conceptual metaphor research which analyse the element te 'hand' in the Japanese idioms. The purpose of this research is to know the te 'hands' image scheme in Japanese idioms and analyze it based on the conceptual metaphors. The data source in this research were taken from the dictionary of idiom "iitai naiyou kara gyakuhiki dekiru reikai kanyouku jiten" by Inoue Muneo. The amount of the data found and analysed were 59 and the amount of data presented were 15. The results of data analysis describe the idiom with the main element of the hand are filled with metaphorical expressions because the hand is the most used body part for activities. The results of the analysis also show eight concepts of hand, which are : HAND as ACTIVITIES/JOB, POSSESSION, LINK, ATTITUDE, TACTICS, CAPABILITY/SKILLS, SUPPORT, and EXPERTISE.

To understand the concept of hand, it is useful to not only use ontological metaphors analysis, but in terms of the hand that has a spatial orientation, it must be analyse with orientational metaphors.
\end{abstract}

Keywords : Cognitive Linguistics, Metaphor, Conceptual Metaphor, Image Scheme, Idioms, Hand

Idiom adalah sebuah ungkapan atau frasa yang terdiri dari dua atau lebih kata yang artinya sama sekali berbeda dengan arti dari masing-masing pembentuknya (Hockett : 1958).

Pada kanyouku terdapat metafora Secara umum pandangan tentang metafora ada dua, yakni klasik atau tradisional dan kognitif. Pandangan klasik menempatkan metafora sebagai bahasa figuratif atau alat stilistik bahasa, atau sarana retorika atau gaya bahasa untuk memperindah tulisan atau karya sastra membuat tulisan yang tidak biasa dengan cara membandingkan dengan sesuatu yang lain dan untuk memahaminya dibutuhkan interpretasi dari pembaca atau pendengarnya (Verspoor, 1993 : 8). Pandangan kedua menurut Lakoff dan Johnson (1980 : 3) menyatakan bahwa metafora merupakan bagian dari sistem berpikir manusia berdasarkan pengalaman atau pengetahuan manusia. Pandangan ini kemudian dikenal dengan teori Metafora Konseptual.

*)Artikel Skripsi Fakultas Ilmu Budaya Universitas Dian Nuswantoro 
Dita Rachmawati, Metafora Tangan dalam Idiom Bahasa Jepang Berdasarkan Teori Metafora Konseptual

Dalam tulisan ini dibahas konseptualisasi te 'tangan' dalam idiom bahasa Jepang dengan menggunakan teori metafora konseptual Lakoff dan Johnson (1980) yang membagi metafora menjadi tiga yaitu struktural, orientasional dan ontologikal.

\section{METODE PENELITIAN}

\section{Sumber Data}

Data yang dikumpulkan berasal dari kamus 言いたい内容から逆引きできる例解 慣用句辞典 iitai naiyou kara gyakuhiki dekiru reikai kanyouku jiten oleh Inoue Muneo.

\section{Satuan Analisis}

Data yang digunakan dalam penelitian ini adalah ungkapan atau frasa yang termasuk dalam idiom yang menggunakan kata te ‘tangan’ pada kamus idiom 言いた い内容から逆引きできる例解慣用句辞典 iitai naiyou kara gyakuhiki dekiru reikai kanyouku jiten oleh Inoue Muneo.

\section{Teknik Pengumpulan dan Analisis}

Teknik pengumpulan data yang dilakukan dalam penelitian ini adalah dengan membaca sumber data dan mengumpulkan data berupa idiom yang menggunakan unsur utama te ‘tangan’ pada kamus 言いたい内容から逆引きできる例解慣用句 辞典 iitai naiyou kara gyakuhiki dekiru reikai kanyouku jiten oleh Inoue Muneo. Data idiom yang ditemukan menggunakan unsur utama te 'tangan' dan dianalisis adalah 59 idiom dan yang ditampilkan dalam bahasan penelitian adalah 15 idiom yang sudah memenuhi tujuan dari penelitian ini. Adapun proses reduksi dari teknik pengumpulan data ini adalah :

1) Mencari idiom yang mengandung unsur utama $t e^{6}$ tangan' dalam kamus $\overline{\bar{D}}$ いたい内容から逆引きできる例解慣用句辞典 iitai naiyou kara gyakuhiki dekiru reikai kanyouku jiten oleh Inoue Muneo karena dalam kamus tersebut terdapat banyak idiom yang mengandung bagian tubuh terutama tangan.

2) Menerjemahkan ke dalam Bahasa Indonesia data idiom yang ditemukan. 
3) Mencari makna sesungguhnya dari ungkapan atau frasa yang ditemukan merujuk pada arti sesungguhnya yang terdapat dalam Kokugo Jiten.

4) Membandingkan makna leksikal dan makna kontekstual dari idiom yang menggunakan unsur utama te 'tangan'.

5) Mengkategorisasikan idiom berdasarkan konsep tangan menurut teori metafora konseptual Lakoff dan Johnson (1980).

6) Mengidentifikasi makna metaforis tangan dengan cara membandingkan dengan makna literal dengan menggunakan kamus.

7) Mengkategorisasi dan menganalisis jenis metafora berdasarkan pembagian metafora dan analisis metafora konseptual menurut Lakoff dan Johnson.

8) Mengidentifikasi skema citra yang mendasari konsep tangan.

9) Memaknai konsep te 'tangan' dalam metafora konseptual.

\section{PEMBAHASAN}

\section{Konsep Tangan sebagai Aktivitas atau Pekerjaan}

Data 1

手を引く(Te wo hiku'menarik tangan')

Terdapat pada kalimat :

1.1 今ここで君に手を引かれては、この計画は一歩も進まないよ。（言いた い内容から逆引きできる例解慣用句辞典, 井上宗雄 : 004)

Ima koko de kimi ni te wo hikarete wa, kono keikaku wa ippou mo susumanai yo. 'Jika sudah sampai di sini, kamu memutuskan hubungan, akan membuat rencana ini tidak bisa melangkah lebih jauh.'

Jika dibandingkan antara makna leksikal/harfiah dan makna kontekstual yang ada pada penerapan idiom te wo hiku seperti pada 1.1, Nampak terdapat perbedaan. Makna leksikal dari te wo hiku adalah menarik tangan, sementara makna kontekstual dalam 1.1 adalah memutuskan hubungan. Berdasarkan jenis metafora konseptual, te wo hiku dapat dapat diidentifikasi sebagai metafora ontologikal dan orientasonal. Sebagai metafora ontologikal karena konsep tangan di sini digunakan untuk mengekspresikan sesuatu atau konsep yang abstrak ke dalam konsep yang konkret, yakni tangan. Kemudian dikategorikan ke dalam metafora orientasional karena dalam 
Dita Rachmawati, Metafora Tangan dalam Idiom Bahasa Jepang Berdasarkan Teori Metafora Konseptual

idiom te wo hiku terdapat unsur yang merupakan penanda posisi atau orientasi, yakni hiku yang bermakna menarik.

Metafora ontologikal tangan dalam te wo hiku

Te 'tangan' dalam te wo hiku yang bermakna metaforis memutuskan hubungan merupakan konseptualisasi dari AKTIVITAS atau PEKERJAAN. Tangan merupakan representasi manusia dalam melakukan aktivitas atau pekerjaan. Tangan bekerja dengan cara menyentuh, meraba, menunjuk, menggenggam dan sebagainya. Pekerjaan tangan dapat langsung bersentuhan dengan objeknya atau pun menggunakan perantara seperti alat sebagai media bantu melakukan pekerjaan (seperti dalam aktivitas menulis, tangan tidak langsung digunakan untuk menulis, melainkan menggunakan pensil atau alat tulis lainnya untuk menulis). Dengan demikian dapat dikatakan bahwa makna tangan berkorespondensi dengan aktivitas atau pekerjaan karena domain yang ada dalam tangan digunakan dalam domain aktivitas atau pekerjaan.

Skema citra yang mendasari konsep tangan sebagai pekerjaan adalah tangan sebagai benda atau objek. Pekerjaan adalah sesuatu yang abstrak dan dikorespondensikan dengan sebuah benda atau objek, yakni tangan yang merupakan benda konkrit.

Metafora orientasional hiku dalam te wo hiku

Analisis metafora orientasional digunakan untuk melengkapi metafora ontologikal, karena kalau hanya dengan analisis ontologikal makna metaforis te wo $h i k u$ yang bermakna tidak turut campur lagi tidak dapat tercapai. Dalam hubungannya dengan makna ontologikal tangan, kata hiku 'menarik' bermakna menarik dan melepaskan kerja sama dari interaksi tangan untuk aktivitas yang sedang dilakukan oleh tangan. Dengan begitu berarti sudah tidak melakukan atau tidak berhubungan dengan pekerjaan atau aktivitas tersebut (tidak ikut campur lagi pada aktivitas tersebut).

Skema citra yang mendasari konsep hiku 'menarik' sebagai tidak terlibat dalam sesuatu adalah citra pisah-sambung. Menarik adalah aktivitas memisahkan sesuatu yang asalnya tersambung. 
Persamaan tangan dan aktivitas/ pekerjaan dalam idiom te wo hiku adalah tangan melakukan aktivitas menarik dan menarik adalah merupakan salah satu aktivitas/pekerjaan.

Hasil Analisis:

Berdasarkan identifikasi skema citra dan analisis metafora konseptual, maka dapat disimpulkan bahwa konsep tangan dalam idiom te wo hiku adalah AKTIVITAS/PEKERJAAN ADALAH TANGAN.

\section{Konsep Tangan sebagai Kepemilikan}

Data 3

手に入れる (Te ni ireru 'memasukkan ke dalam tangan')

Terdapat pada kalimat

3.1 こここつ貯めた貸金でやっと土地を手に入れることができた。（言いた い内容から逆引きできる例解慣用句辞典, 井上宗雄 : 268)

Kotsu kotsu tameta kashikin de yatto tochi wo te ni ireru koto ga dekita.

'Akhirnya saya memiliki sendiri tanah dengan uang pinjaman yang saya kumpulkan dengan giat.'

Jika dibandingkan antara makna leksikal/harfiah dan makna kontekstual yang ada pada penerapan idiom te ni ireru seperti pada 3.1, nampak terdapat perbedaan. Makna leksikal dari te ni ireru adalah memasukkan ke dalam tangan, sementara makna kontekstual dalam 3.1 adalah memiliki sendiri. Berdasarkan jenis metafora konseptual, te ni ireru dapat dapat diidentifikasi sebagai metafora ontologikal. Sebagai metafora ontologikal karena konsep tangan di sini digunakan untuk mengekspresikan sesuatu atau konsep yang abstrak, yakni kepemilikan ke dalam konsep yang konkret, yakni tangan. Te 'tangan' dalam te ni ireru yang bermakna metaforis memiliki sendiri merupakan konseptualisasi dari KEPEMILIKAN. Konsep kepemilikan didasari dari skema citra sebagai wadah, yakni tempat menyimpan yang mempunyai ruang dan dibatasi oleh sesuatu yang menjadi pembatas antara dalam dan luar wadah. Sesuatu yang berada di dalam wadah menjadi milik atau bagian dari wadah tersebut, dan sebaliknya jika berada di luar wadah berarti bukan menjadi bagiannya. Dalam idiom te ni ireru, sesuatu yang dari luar yang tadinya tidak berada 
Dita Rachmawati, Metafora Tangan dalam Idiom Bahasa Jepang Berdasarkan Teori Metafora Konseptual

di dalam, masuk ke dalam tangan dan menjadi bagian dari tangan dan digenggam. Genggaman tangan yakni jari-jari membatasi antara ruang dalam dan luar.

Persamaan tangan dan kepemilikan dalam te ni ireru adalah tangan sebagai wadah atau tempat untuk menampung sesuatu sebagai miliknya, kepemilikan berarti memiliki sesuatu atau menjadi wadah akan sesuatu.

Hasil Analisis:

Berdasarkan analisis metafora konseptual makna te ni ireru 'memasukkan ke dalam tangan' dapat dikonseptualisasi sebagai KEPEMILIKAN ADALAH TANGAN. Sesuatu yang berada di dalam tangan (genggaman tangan) menjadi milik dari pemilik tangan.

\section{Konsep Tangan sebagai Hubungan}

Data 5

手に手を取る(Te ni te wo toru 'mengambil tangan ke dalam tangan')

Terdapat pada kalimat :

5.1 二十年前、手に手を取って故郷を後にしたのだが、当座はずいぶん苦 労もしたものだ。(言いたい内容から逆引きできる例解慣用句辞典, 井上 宗雄 : 233)

Ni juu nen mae, te ni te wo totte furusato wo ushiro ni shita ga, touza wa zuibun kurou mo shita mono da.

'Dua puluh tahun yang lalu, telah meninggalkan kampung halaman dengan bersama-sama membangun hubungan dan untuk sementara mengalami cukup banyak penderitaan.'

Jika dibandingkan antara makna leksikal/harfiah dan makna kontekstual yang ada pada penerapan idiom te ni te wo toru seperti pada 5.1, Nampak terdapat perbedaan. Makna leksikal dari te ni te wo toru adalah mengambil tangan ke dalam tangan, sementara makna kontekstual dalam 5.1 adalah bersama-sama membangun hubungan. Oleh karena itu dapat dikatakan bahwa te ni te wo toru dalam 5.1 adalah idiom yang merupakan ekspresi metaforis. Berdasarkan jenis metafora konseptual, te ni te wo toru dapat diidentifikasi sebagai metafora ontologikal. Sebagai metafora 
ontologikal karena konsep tangan di sini digunakan untuk mengekspresikan sesuatu atau konsep yang abstrak ke dalam konsep yang konkret, yakni tangan.

Te 'tangan' dalam te ni te wo toru yang bermakna metaforis membina hubungan (dalam konteks kalimat data ini dapat bermakna menikah). Dalam data ini terdapat dua kata te, yakni te ni dan te wo toru. Te yang pertama bermakna metafora kepemilikan, sama seperti pada data sebelumnya yang mempunyai konsep KEPEMILIKAN. Kemudian te yang kedua (te wo toru) merupakan konseptualisasi dari HUBUNGAN. Tangan merupakan representasi manusia dalam melakukan aktivitas atau pekerjaan. Tangan juga dapat merepresentasikan adanya hubungan antara satu orang dengan orang yang lain seperti berjabat tangan. Dengan demikian dapat dikatakan bahwa makna tangan berkorespondensi dengan hubungan karena domain yang ada dalam tangan digunakan dalam domain hubungan.

Skema citra dari te ni adalah tangan sebagai wadah dan pada te wo toru adalah hubungan. Dalam penjelasan yang lebih mudah adalah mengambil tangan (mengambil seseorang: membina hubungan) untuk dijadikan milik.

Persamaan tangan dengan hubungan dalam idiom te ni te wo toru adalah tangan sama dengan hubungan dalam melakukan suatu aktivitas untuk membina hubungan satu orang dengan orang lain.

Hasil Analisis:

Temuan dari hasil analisisnya adalah konsep KEPEMILIKAN ADALAH TANGAN dan HUBUNGAN ADALAH TANGAN.

\section{Konsep Tangan sebagai Sikap}

Data 6

手の裏を返す(Te no ura wo kaesu 'membalik punggung tangan')

Makna :

急に態度をがらりと変えてる。「手を返す」とも。類 : 手の平を返す。（言い たい内容から逆引きできる例解慣用句辞典, 井上宗雄 : 174)

Kyиu ni taido wo garari to kaeteru. (te wo kaesu) tomo. Rui : te no hira wo kaesu. Perubahan sikap yang tiba-tiba berbeda. Juga dengan te wo kaesu. Serupa : te no hira wo kaesu. 
Dita Rachmawati, Metafora Tangan dalam Idiom Bahasa Jepang Berdasarkan Teori Metafora Konseptual

Terdapat pada kalimat :

6.1 左遷が決まったとたん、同僚たちは手の裏を返すように私に寄りつかな くなった。類 : 手の平を返す。（言いたい内容から逆引きできる例解慣 用句辞典, 井上宗雄 : 174)

Sasen ga kimatta totan, douryou tachi wa te no ura wo kaesu you ni watashi ni yori tsukanaku natta.

'Saat mutasi saya diputuskan, para rekan tidak ada yang menghampiri saya bagaikan membalik punggung tangan'.

Makna metaforis te no ura wo kaesu: perubahan sikap yang tiba-tiba.

Jika dibandingkan antara makna leksikal/harfiah dan makna kontekstual yang ada pada penerapan idiom te no ura wo kaesu seperti pada 6.1, nampak terdapat perbedaan. Makna leksikal dari te no ura wo kaesu adalah membalikkan punggung tangan, sementara makna kontekstual dalam 6.1 adalah perubahan sikap yang tibatiba.

Berdasarkan jenis metafora konseptual, te no ura wo kaesu dapat diidentifikasi sebagai metafora ontologikal dan orientasonal. Sebagai metafora ontologikal karena konsep tangan di sini digunakan untuk mengekspresikan sesuatu atau konsep yang abstrak ke dalam konsep yang konkret, yakni tangan. Kemudian dikategorikan ke dalam metafora orientasional karena dalam idiom te no ura wo kaesu terdapat unsur yang merupakan penanda posisi atau orientasi, yakni kaesu yang bermakna membalik sehingga untuk dapat memahami makna metaforis idiom seperti ini diperlukan dua analisis, yakni analisis metafora ontologikal dan orientasional.

Metafora ontologikal tangan dalam te no ura wo kaesu

Te 'tangan' dalam te no ura wo kaesu yang bermakna metaforis perubahan sikap yang tiba-tiba merupakan konseptualisasi dari SIKAP (dalam melakukan atau mengelola pekerjaan). Tangan merupakan representasi manusia dalam melakukan aktivitas atau pekerjaan. Tangan bekerja dengan cara menyentuh, meraba, menunjuk, menggenggam dan sebagainya. Pekerjaan tangan dapat langsung bersentuhan dengan objeknya atau pun menggunakan perantara seperti alat sebagai media bantu melakukan pekerjaan (seperti dalam aktivitas menulis, tangan tidak langsung 
digunakan untuk menulis, melainkan menggunakan pensil atau alat tulis lainnya untuk menulis). Dengan demikian dapat dikatakan bahwa makna tangan berkorespondensi dengan sikap karena domain yang ada dalam tangan digunakan dalam domain sikap.

Skema citra dari te no adalah tangan sebagai benda. Sikap seseorang dicitrakan seolah-olah sebagai benda konkrit yang dapat dibolak-balik.

Metafora orientasional kaesu dalam te no ura wo kaesu

Analisis metafora orientasional digunakan untuk melengkapi metafora ontologikal, karena kalau hanya dengan analisis ontologikal makna metaforis te no ura wo kaesu yang bermakna perubahan sikap yang tiba-tiba tidak dapat tercapai. Dalam hubungannya dengan makna ontologikal tangan, kata kaesu 'membalik' bermakna membalik atau tidak konsisten dalam melakukan interaksi tangan dari aktivitas yang sedang dilakukan oleh tangan. Dengan begitu berarti dalam menangani suatu pekerjaan tersebut tidak ditangani secara tetap atau berubah-ubah sesuai kondisi atau dapat dikatakan sudah tidak konsisten dalam melakukan pekerjaan atau aktivitas.

Skema citra dari ura wo kaesu adalah perubahan, dalam hal ini adalah perubahan orientasi yang drastis, 180 derajat.

Persamaan tangan dan sikap dalam te no ura wo kaesu adalah tangan sama dengan sikap yang dapat berubah orientasinya.

Hasil Analisis:

Berdasarkan kedua analisis tersebut makna te no ura wo kaesu 'membalik punggung tangan' dapat dikonseptualisasi sebagai PERUBAHAN SIKAP ADALAH MEMBALIK TANGAN (CHANGING ATTITUDE IS TURN OVER). Dengan demikian citra tangan dalam idiom te no ura wo kaesu adalah sebagai sikap. Idiom ini serupa dengan te no hira wo kaesu.

\section{Konsep Tangan sebagai Siasat}

Data 8

手に乗る (te ni noru 'menaiki tangan')

Terdapat pada kalimat :

8.1 この間さんざんな目にあわされたから、もうその手に乗らないよ。（言 いたい内容から逆引きできる例解慣用句辞典, 井上宗雄 : 285) 
Dita Rachmawati, Metafora Tangan dalam Idiom Bahasa Jepang Berdasarkan Teori Metafora Konseptual

Kono aida sanzan na me ni awasaretakara, mo sono te ni noranaiyo.

'Karena selama ini sudah mengalami banyak hal, saya tidak akan terjebak siasat itu lagi.'

Jika dibandingkan antara makna leksikal/harfiah dan makna kontekstual yang ada pada penerapan idiom te ni noru seperti pada 8.1, nampak terdapat perbedaan. Makna leksikal dari te ni noru adalah menaiki tangan, sementara makna kontekstual dalam 8.1 adalah terjebak siasat. Berdasarkan jenis metafora konseptual, te ni noru dapat diidentifikasi sebagai metafora ontologikal dan orientasonal. Sebagai metafora ontologikal karena konsep tangan di sini digunakan untuk mengekspresikan sesuatu atau konsep yang abstrak ke dalam konsep yang konkret, yakni tangan. Kemudian dikategorikan ke dalam metafora orientasional karena dalam idiom te ni noru terdapat unsur yang merupakan penanda posisi atau orientasi, yakni noru yang bermakna naik. Sehingga untuk dapat memahami makna metaforis idiom seperti ini diperlukan dua analisis, yakni analisis metafora ontologikal dan orientasional.

Metafora ontologikal tangan dalam te ni noru

Te 'tangan' dalam te ni noru yang bermakna terjebak siasat merupakan konseptualisasi dari SIASAT (dalam melakukan atau mengelola pekerjaan). Tangan merupakan representasi manusia dalam melakukan aktivitas atau pekerjaan. Tangan bekerja dengan cara menyentuh, meraba, menunjuk, menggenggam dan sebagainya. Pekerjaan tangan dapat langsung bersentuhan dengan objeknya atau pun menggunakan perantara seperti alat sebagai media bantu melakukan pekerjaan (seperti dalam aktivitas menulis, tangan tidak langsung digunakan untuk menulis, melainkan menggunakan pensil atau alat tulis lainnya untuk menulis). Dengan demikian dapat dikatakan bahwa makna tangan berkorespondensi dengan sikap karena domain yang ada dalam tangan digunakan dalam domain sikap.

Skema citra dari te adalah tangan sebagai wadah. Siasat seseorang dicitrakan seolah-olah sebagai wadah. Sesuatu yang berada di dalam wadah menjadi berada dalam kekuasaan wadah.

Metafora orientasional noru dalam te ni noru

Analisis metafora orientasional digunakan untuk melengkapi metafora ontologikal, karena kalau hanya dengan analisis ontologikal makna metaforis te $n i$ 
noru yang bermakna terjebak siasat tidak dapat tercapai. Dalam hubungannya dengan makna ontologikal tangan, kata noru 'naik (moda transportasi)' bermakna tangan yang merepresentasikan manusia menaiki atau menunggangi, meraih sesuatu yang akan dilakukan interaksi tangan pada aktivitas yang sedang dilakukan tangan. Dengan begitu berarti telah terjebak oleh suatu cara atau siasat lawan.

Skema citra dari noru adalah posisi masuk-keluar. Tangan di dalam data ini dianggap sebagai sebuah wadah yang berada di atas dan untuk memasukinya harus menaikinya. Aktivitas naik dilakukan oleh kaki yang posisinya berada di bawah tangan.

Persamaan tangan dengan siasat dalam te ni noru adalah tangan sama dengan siasat yang dapat digunakan untuk menjebak lawan.

Hasil Analisis:

Berdasarkan kedua analisis tersebut makna te ni noru 'menaiki tangan' dapat dikonseptualisasi sebagai MASUK KE DALAM SIASAT LAWAN.

\section{Konsep Tangan sebagai Kemampuan/Keterampilan}

Data 10

お手上げ (Oteage 'angkat tangan')

Terdapat pada kalimat :

10.1 急に福岡への出張が決まったが、台風で飛行機が欠航となったうえ、 新幹線の切符も取れないとあって、まったくのお手上げだ。（言いたい 内容から逆引きできる例解慣用句辞典, 井上宗雄 : 003)

Kуии ni Fukuoka e shucchou ga kimattaga, taifu de hikouki ga kekkou to nattaue, shinkansen no kippu mo torenai to atte, mattaku no oteage da.

'Saya memutuskan untuk dinas ke Fukuoka dengan mendadak tetapi karena angin topan penerbangan dibatalkan, dan sudah tidak bisa membeli tiket Shinkansen, benar-benar saya sudah menyerah.'

Jika dibandingkan antara makna leksikal/harfiah dan makna kontekstual yang ada pada penerapan idiom oteage seperti pada 10.1, nampak terdapat perbedaan. Makna leksikal dari oteage adalah angkat tangan, sementara makna kontekstual 
Dita Rachmawati, Metafora Tangan dalam Idiom Bahasa Jepang Berdasarkan Teori Metafora Konseptual

dalam 10.1 adalah menyerah. Berdasarkan jenis metafora konseptual, oteage dapat diidentifikasi sebagai metafora ontologikal dan orientasonal.

Metafora ontologikal tangan dalam oteage

Te 'tangan' dalam oteage yang bermakna metaforis menyerah merupakan konseptualisasi dari KEMAMPUAN atau KETERAMPILAN (dalam melakukan atau mengelola pekerjaan). Tangan merupakan representasi manusia dalam melakukan aktivitas atau pekerjaan. Tangan bekerja dengan cara menyentuh, meraba, menunjuk, menggenggam dan sebagainya. Pekerjaan tangan dapat langsung bersentuhan dengan objeknya ataupun menggunakan perantara seperti alat sebagai media bantu melakukan pekerjaan (seperti dalam aktivitas menulis, tangan tidak langsung digunakan untuk menulis, melainkan menggunakan pensil atau alat tulis lainnya untuk menulis). Dengan demikian dapat dikatakan bahwa makna tangan berkorespondensi dengan kemampuan karena domain yang ada dalam tangan digunakan dalam domain kemampuan.

Skema citra tangan yang mendasari konsep KEMAMPUAN atau KETERAMPILAN adalah tangan sebagai benda atau alat yang digunakan untuk mengerjakan sesuatu.

Metafora orientasional age dalam oteage

Analisis metafora orientasional digunakan untuk melengkapi metafora ontologikal, karena kalau hanya dengan analisis ontologikal makna metaforis oteage yang bermakna menyerah tidak dapat tercapai. Dalam hubungannya dengan makna ontologikal tangan, kata age 'angkat' bermakna mengangkat atau melepaskan interaksi tangan dari aktivitas yang sedang dilakukan oleh tangan. Dengan begitu berarti sudah tidak dapat lagi menangani pekerjaan tersebut atau dapat dikatakan sudah tidak mempunyai kemampuan untuk mengerjakannya (menyerah dalam menyelesaikan tugasnya).

Skema citra yang mendasarinya adalah citra naik-turun atau atas-bawah. Naik berarti menjauhkan dari pekerjaan dan turun berarti menangani pekerjaan.

Persamaan tangan dengan kemampuan/keterampilan dalam oteage adalah tangan sama dengan kemampuan/keterampilan yaitu sebagai benda atau alat untuk mengerjakan sesuatu. 
Hasil Analisis:

Berdasarkan kedua analisis tersebut makna oteage 'angkat tangan' dapat dikonseptualisasi sebagai MENYERAH ADALAH ATAS dan KEMAMPUAN/ KETERAMPILAN ADALAH TANGAN.

\section{Konsep Tangan sebagai Bantuan}

Data 12

手を貸す (te wo kasu 'meminjamkan tangan')

Terdapat pada kalimat :

12.1 一人で大丈夫ですか。なんなら手を貸しましょうか。（言いたい内容か ら逆引きできる例解慣用句辞典, 井上宗雄 : 279)

Hitori de daijoubi desuka. Nan nara te wo kashimasyouka.

'Apakah tidak apa-apa sendiri? kalau tidak keberatan saya akan membantu?'

Jika dibandingkan antara makna leksikal/harfiah dan makna kontekstual yang ada pada penerapan idiom te wo kasu seperti pada 12.1, nampak terdapat perbedaan. Makna leksikal dari te wo kasu adalah meminjamkan tangan, sementara makna kontekstual dalam 12.1 adalah membantu seseorang. Berdasarkan jenis metafora konseptual, te wo kasu dapat diidentifikasi sebagai metafora ontologikal. Sebagai metafora ontologikal karena konsep tangan di sini digunakan untuk mengekspresikan sesuatu atau konsep yang abstrak ke dalam konsep yang konkret, yakni tangan.

Metafora ontologikal tangan dalam te wo kasu

Te 'tangan' dalam te wo kasu yang bermakna metaforis membantu seseorang merupakan konseptualisasi dari BANTUAN (dalam melakukan atau mengelola pekerjaan). Tangan merupakan representasi manusia dalam melakukan aktivitas atau pekerjaan. Tangan bekerja dengan cara menyentuh, meraba, menunjuk, menggenggam dan sebagainya. Pekerjaan tangan dapat langsung bersentuhan dengan objeknya atau pun menggunakan perantara seperti alat sebagai media bantu melakukan pekerjaan (seperti dalam aktivitas menulis, tangan tidak langsung digunakan untuk menulis, melainkan menggunakan pensil atau alat tulis lainnya untuk menulis). Dengan demikian dapat dikatakan bahwa makna tangan berkorespondensi dengan bantuan karena domain yang ada dalam tangan digunakan dalam domain bantuan. 
Dita Rachmawati, Metafora Tangan dalam Idiom Bahasa Jepang Berdasarkan Teori Metafora Konseptual

Skema citra tangan yang mendasari konsep BANTUAN adalah tangan sebagai benda atau alat yang digunakan untuk mengerjakan sesuatu.

Persamaan tangan dengan bantuan dalam te wo kasu adalah tangan sama dengan bantuan yaitu sebagai benda atau alat untuk mengerjakan sesuatu.

Hasil Analisis:

Berdasarkan kedua analisis tersebut makna te wo kasu 'meminjamkan tangan' dapat dikonseptualisasi sebagai TANGAN ADALAH BANTUAN.

\section{Konsep Tangan sebagai Keahlian/Kepandaian}

Data 14

お手の物(Ote no mono ‘benda milik tangan’)

Terdapat pada kalimat :

14.1 彼は専門の学校を出ているから、パソコンの修理ぐらいは手の物だよ。

(言いたい内容から逆引きできる例解慣用句辞典, 井上宗雄 : 150)

Kare wa senmon no gakkou wo dete iru kara, pasokon no shuuri gurai wa te no mono dayo.

'Dia, karena lulus dari sekolah kejuruan, kalau hanya memperbaiki komputer itu sudah menjadi hal yang dikuasainya.'

Jika dibandingkan antara makna leksikal/harfiah dan makna kontekstual yang ada pada penerapan idiom ote no mono seperti pada 14.1, Nampak terdapat perbedaan. Makna leksikal dari ote no mono adalah benda milik tangan, sementara makna kontekstual dalam 14.1 adalah hal yang dikuasai. Berdasarkan jenis metafora konseptual, ote no mono dapat diidentifikasi sebagai metafora ontologikal. Sebagai metafora ontologikal karena konsep tangan di sini digunakan untuk mengekspresikan sesuatu atau konsep yang abstrak ke dalam konsep yang konkret, yakni tangan.

Metafora ontologikal tangan dalam ote no mono

Te 'tangan' dalam Ote no mono yang bermakna metaforis hal yang dikuasai merupakan konseptualisasi dari KEAHLIAN atau KEPANDAIAN (dalam melakukan atau mengelola pekerjaan). Tangan merupakan representasi manusia dalam melakukan aktivitas atau pekerjaan.Tangan bekerja dengan cara menyentuh, meraba, menunjuk, menggenggam dan sebagainya. Pekerjaan tangan dapat langsung 
bersentuhan dengan objeknya atau pun menggunakan perantara seperti alat sebagai media bantu melakukan pekerjaan (seperti dalam aktivitas menulis, tangan tidak langsung digunakan untuk menulis, melainkan menggunakan pensil atau alat tulis lainnya untuk menulis). Dengan demikian dapat dikatakan bahwa makna tangan berkorespondensi dengan keahlian karena domain yang ada dalam tangan digunakan dalam domain keahlian.Dengan begitu berarti memiliki suatu kemampuan untuk menggenggam sesuatu benda dalam hal ini benda adalah suatu keahlian yang dimiliki oleh diri sendiri.

Skema citra tangan yang mendasari konsep KEAHLIAN/KEPANDAIAN adalah tangan sebagai wadah, apa yang ada di dalamnya adalah menjadi kekuasaan atau sesuatu yang dikuasai.

Persamaan tangan dengan keahlian/kepandaian dalam ote no mono adalah tangan sama sebagai keahlian/kepandaian yaitu apa yang ada di dalamnya adalah menjadi kekuasaan atau sesuatu yang dikuasai.

Hasil Analisis:

Berdasarkanan analisis tersebut makna ote no mono 'benda milik tangan' dapat dikonseptualisasi sebagai MENGGENGGAM DI TANGAN ADALAH KEAHLIAN. Dengan demikian konsep tangan dalam idiom ote no mono adalah sebagai keahlian.

\section{Simpulan}

Berdasarkan pembahasan dari proses identifikasi dan analisis idiom yang menggunakan unsur utama te ‘tangan’yang terdapat pada kamus 言いたい内容から 逆引きできる例解慣用句辞典 iitai naiyou kara gyakuhiki dekiru reikai kanyouku jiten oleh Inoue Muneo, maka bisa diambil kesimpulan bahwa te atau tangan adalah suatu bagian tubuh yang paling banyak digunakan untuk beraktivitas sehingga menjadikan te sangat kaya akan ekspresi metaforis yang menghasilkan delapan konsep yaitu: TANGAN sebagai AKTIVITAS/PEKERJAAN, KEPEMILIKAN, HUBUNGAN, SIKAP, SIASAT, KEMAMPUAN/KETERAMPILAN, BANTUAN, dan KEAHLIAN/KEPANDAIAN.

Skema citra tangan yang dihasilkan dalam penelitian ini adalah sebagai entitas, yakni wadah atau benda yang menjadi dasar dari delapan konsepsi tangan. Delapan 
Dita Rachmawati, Metafora Tangan dalam Idiom Bahasa Jepang Berdasarkan Teori Metafora Konseptual

konsep abstrak yang oleh orang Jepang direpresentasikan dalam konsep yang konkrit yakni tangan.

Penelitian ini juga menghasilkan temuan bahwa untuk memaknai atau mengkonseptualisasi (dalam linguistik kognitif makna diartikan sebagai konsep) tangan diperlukan tidak hanya metafora ontologis karena ternyata tangan juga berhubungan dengan orientasi spasial, yakni posisi tangan ketika melakukan suatu pekerjaan. Oleh karena itu dalam hal tangan yang berhubungan dengan posisi harus dilengkapi dengan analisis metafora orientasional.

\section{Saran}

Pada penelitian ini penulis telah menganalisis idiom dengan unsur utama te ‘tangan’ pada kamus 言いたい内容から逆引きできる例解慣用句辞典 iitai naiyou kara gyakuhiki dekiru reikai kanyouku jiten oleh Inoue Muneo dengan analisis metafora konseptual, akan tetapi penulis hanya meneliti idiom yang mengandung unsur utama te 'tangan' sedangkan idiom yang menggunakan unsur tangan walaupun bukan unsur utama serta idiom-idiom yang menggunakan unsur bagian-bagian tubuh masih sangat banyak sekali, maka diharapkan hal ini dapat menjadi penelitian lanjutan bagi mahasiswa yang masih belajar tentang linguistik bahasa Jepang terutama untuk metafora konseptual dan linguistik kognitif.

\section{Daftar Pustaka}

Citraresmana, E. (2011). Kontruksi Middle Passive (MP) Bahasa Inggris: Pendekatan Metafora Semantik Kognitif. Bandung. Universitas Padjadjaran. Fakultas Ilmu Budaya.

Cruse, D. A. dan Croft, W. (2004). Cognitive Linguistisc. Cambridge: Cambridge University Press.

Fan, H. (2017). A Study of "Hand” Metaphors in English and Chinese, Cognitive and Cultural Perspective. Advances in Literary Study, (5), 89-93. School of Foreign Studies, Yangtze University, Jingzhou, China.

Hockett, C.F. (1958). A Course in Modern Linguistics. New York : The Macmillan Company.

Hyun, J.A. \& Yeon, J.K. (2007). A Study on Metaphor and Metonimy of hand. Journal of Language Science, (14-2), 195-215. Pusan International University. 
Indriyati. (2010). Idiom Bahasa Jepang yang Menggunakan Kata Te (Keterkaitan Semantik Leksikal dan Kiasan). Universitas Dian Nuswantoro.

Inoue, M. (2015). Iitai Naiyou Kara Gyakuhiki Dekiru Reikai Kanyouku Jiten. Tokyo : Soutakushashuppan.

Knowles, M. and Rosamund M. (2006). Introducing Methaphor. London and New York: Routledge.

Kovecses, Z. (2010). Metaphor A Practical Introduction. New York: Oxford University Press.

Lakoff, G. and Jhonson, M. (1980). Methaphors We Live By. Chicago: The University of Chicago Press.

Matsuura, Kenji. (1994). Kamus Bahasa Jepang-Indonesia. Kyoto: Kyoto Sango University Press.

Saeed, Jhon I. 2003. Semantics. Oxford: Blackwell Publisher Ltd.

Saifudin, Akhmad. (2012). Metafora dalam Lirik Lagu Kokoro no Tomo Karya Itsuwa Mayumi. LITE, 8(2), 89-105.

Saifudin, Akhmad. (2018). Konseptualisasi Citra Hara 'Perut' dalam Idiom Bahasa Jepang. Japanese Research on Linguistics, Literature, and Culture, 1 (1), 67-78. Sarmidi. (2016). Interaksi Makna Leksikal dalam Novel Minna Kodoku Dakedo Karya Takashi Kitajima. Universitas Dian Nuswantoro.

Swasono, R. N. (2013). Metafora dalam Idiom Bahasa Jepang yang Mengandung Unsur 花dan 猫. Universitas Dian Nuswantoro.

Swasono, R. N. \& Saifudin, Akhmad. (2013). Makna Idiom Hana dalam Perspektif Budaya Orang Jepang. In Simposium Nasional ASJI (pp. 1-15). Semarang: Universitas Dian Nuswantoro. 